\title{
608
}

\author{
建築材料の耐火試験シミュレーション

\section{Numerical Simulation of the Fire Resistance Tests for Structural Parts of Building Construction}

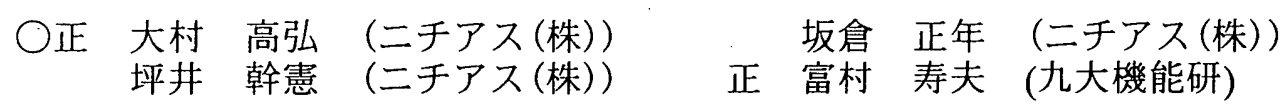

Takahiro OHMURA, NICHIAS Corp., Shin - Miyakoda 1-8-1, Hamamatsu, Shizuoka Masatoshi SAKAKURA, NICHIAS Corp., Shin - Miyakoda 1-8-1, Hamamatsu, Shizuoka Mikinori TSUBOI, NICHIAS Corp., Shin - Miyakoda 1-8-1, Hamamatsu, Shizuoka Toshio TOMIMURA, Institute of Advanced Material Study, Kyushu University,

Kasuga - Koen 6 - 1, Kasuga, Fukuoka

Key Words : Numerical Simulation, Network method, Fire Resistance Test, Building Construction

\section{1. 緒言}

建築基準法では、都市火災を減少させる目的から、都 市計画区域内における防火地域、準防火地域を指定し、 建築物に対し耐火構造や防火構造を要求している。その ため、各種研究機関において盛んに耐火構造が研究され ており、様々な構造の耐火壁が開発されている。

このような壁体の耐火性能の優劣を判断する重要な ファクターの一つとして耐火試験があり、これは、一般 的にJIS（JIS A 1304）やIS0 で示された方法によって実 施される(1)。しかし、その試験設備は非常に大がかりで あり、試験体作りや試験にかかる費用之時間は莫大なも のとなっている。そのため、試行錯誤的な要因を多く含 む材料開発の分野においては、自ずと試験回数が限られ てしまう。そこで、筆者らは、耐火構造之試験結果の関 係を予測するための数值シミュレーションコードの開 発を試みている。ここでは、その第一ステップとして、 1 次元積層耐火壁モデルに関して得られた数值解析結果 について報告する。

\section{2. 解析モテル}

シミュレーション対象とした耐火試験系の概要を図 1 に示す。試験炉の寸法は高さ約 $3 \mathrm{~m} 、$ 幅約 $2 \mathrm{~m}$ であり、 炉壁には高さ方向に 5 個、幅方向に 3 個の計 15 個のバ

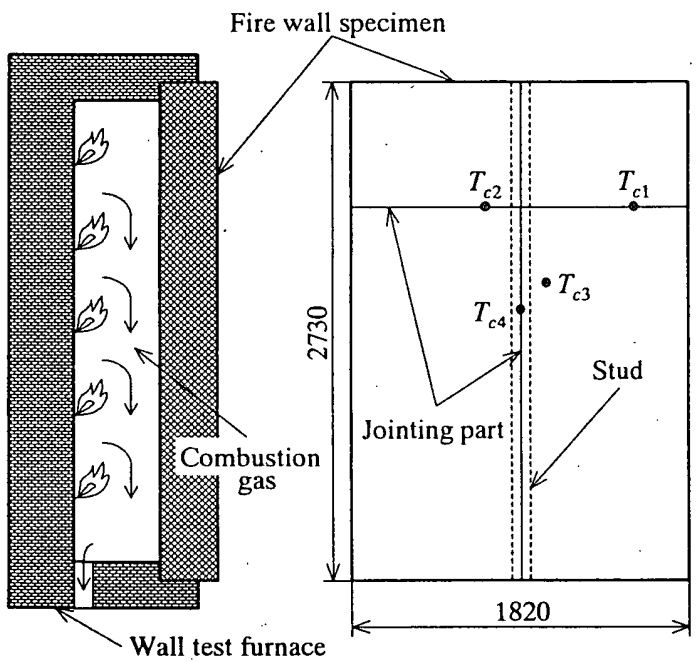

Fig. 1 Schematic of fire resistance test system
一ナーが設けられている。試験用の耐火壁は炉壁と平行 に設置され、その片面が IS0-834 で規定される次式の昇 温曲線に従う燃焼カスによって加熱される。

$$
T_{g}=345 \log _{10}(8 t+1)+T_{a}
$$

ここで、 $T_{g}$ は燃焼ガス温度 $\left[{ }^{\circ} \mathrm{C}\right] 、 T_{\mathrm{a}}$ は周囲空気温度 $\left[{ }^{\circ} \mathrm{C}\right]$ 、 $t$ は時間 [min]である。試験時間は 1 時間から 2 時間であ り、その時点での裹面側 (周囲空気側) 壁面の温度上昇量 によって壁体の耐火性能が評価される。

耐火試験で使用した壁体は図 2 の左図に示す積首型 耐火壁である。積層順にケイ酸カルシュウム板 $\left(8 \mathrm{~mm}^{1}\right)+$ ケイ酸カルシュウム板 $\left(8 \mathrm{~mm}^{\mathrm{l}}\right)+$ 空気ギャッブ(約 $\left.2 \mathrm{~mm}^{\mathrm{l}}\right)+$ ロ ックウール断熱材 $\left(50 \mathrm{~mm}^{\prime}\right)+$ 空気ギャッブ(約 $\left.2 \mathrm{~mm}^{\prime}\right)+$ ケイ 酸カルシュウム板 $\left(8 \mathrm{~mm}^{1}\right)+$ ケイ酸カルシュウム板 $\left(8 \mathrm{~mm}^{2}\right)$ である。なお、本試験体は大小 4 枚の壁体で構成されて おり、図 1 の右図に示した試験体中の実線はその接合面 である継ぎ目 (Jointing part)を表す。また、ロックウ 一ル断熱材の層内には耐火壁補強用の金属スタッド(間 柱、図 1 の右図中の破線)が縦に 1 本通されている。耐 火壁の裏面側温度は主要箇所 19 点に設けたシース熱電 対によって測定したが、ここでは図 1 に○で示した 4 点 の温度 $T_{c 1} \sim T_{c 4}$ について数值解析結果と比較・検討する。

解析の第一ステップとして、壁体間の継ぎ目および金 属スタッド(間柱)を省略し、図 2 に示す 1 次元の耐火壁 の場合についてネットワーク法を適用した数値シミュ

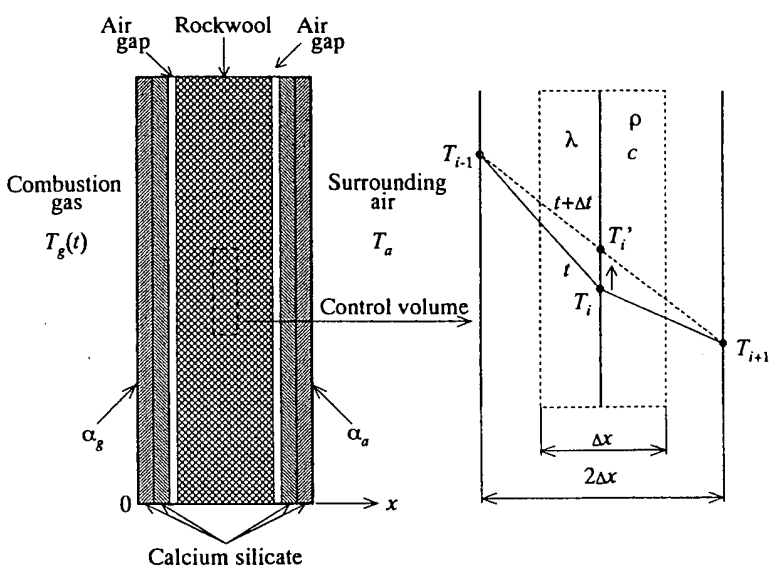

Fig. 2 Physical model of fire wall and coordinate system 


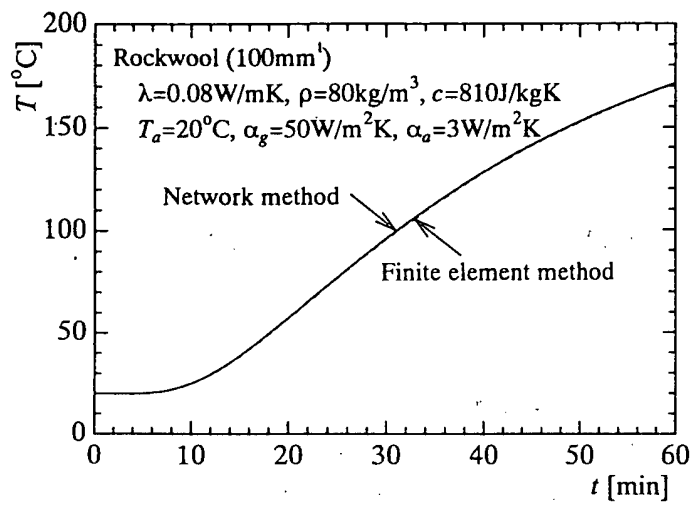

Fig. 3 Comparison between present network method and finite element method
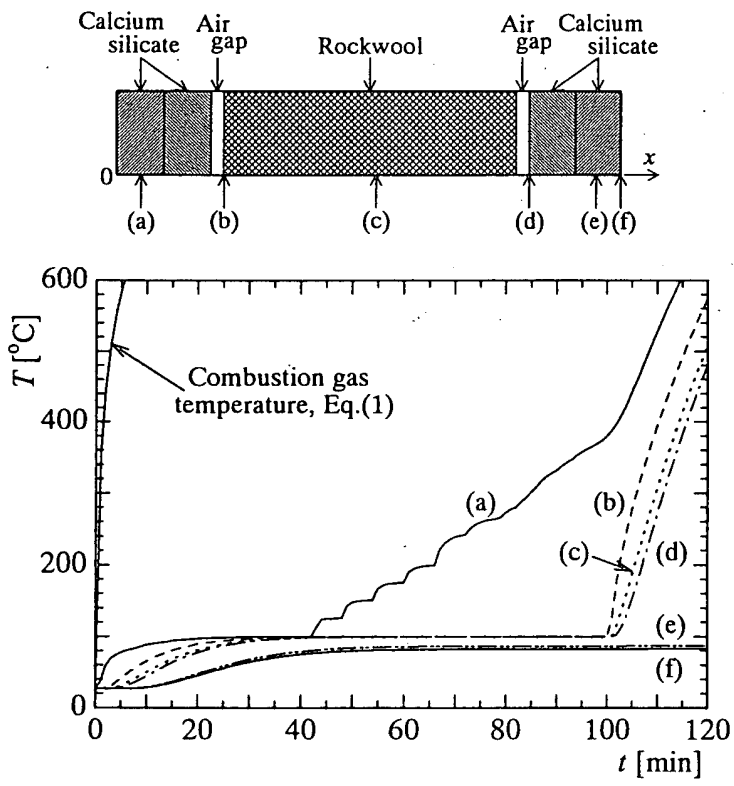

Fig. 4 Numerical result for fire wall

レーションを行った。一様温度 $T_{a}$ に保たれた積層壁が、 時刻 $\mathrm{t}=0$ で $\mathrm{x}=0$ の面側から式 (1)の昇温曲線に従う燃焼 ガスによって加熱される。ここで、 $\alpha_{g}$ と $\alpha_{a}$ は、それぞ れ、加熱面側と裹面側の熱伝達係数である。壁内部では、 図 2 に例示したように、各層毎に適当な間隔で格子点を 設定し、時刻 $t=t+\Delta t$ における各格子点温度を次式に基 づく陽解法により計算した。

$$
\lambda \frac{T_{i-1}-T_{i}}{\Delta x} \Delta t-\lambda \frac{T_{i}-T_{i+1}}{\Delta x} \Delta t=\rho c \Delta x\left(T_{i}^{\prime}-T_{i}\right)
$$

ここで、入は熱伝導率、 $\rho$ は嵩密度、 $c$ は比熱、 $i-1 、 i 、$ $i+1$ は格子点番号、’は時刻 $t=t+\Delta t$ における值である。 なお、本解析ではケイ酸カルシュウム板に含まれる水分 の蒸発の影響を考慮するため、格子点温度が $100^{\circ} \mathrm{C}$ に達 した段階で、微小体積要素内の水分が完全に蒸発するま で、その格子点温度を $100^{\circ} \mathrm{C} に$ 保持し続けるようにした。

\section{3. 結果及び考察}

本解析ではネットワーク法による陽解法を適用して数 值シミュレーションを行っているが、まずそのプログラ ムコードの健全性を確認するため、有限要素法(サイバー ネットシステム(桻) ANSYS)による解析結果との比較を

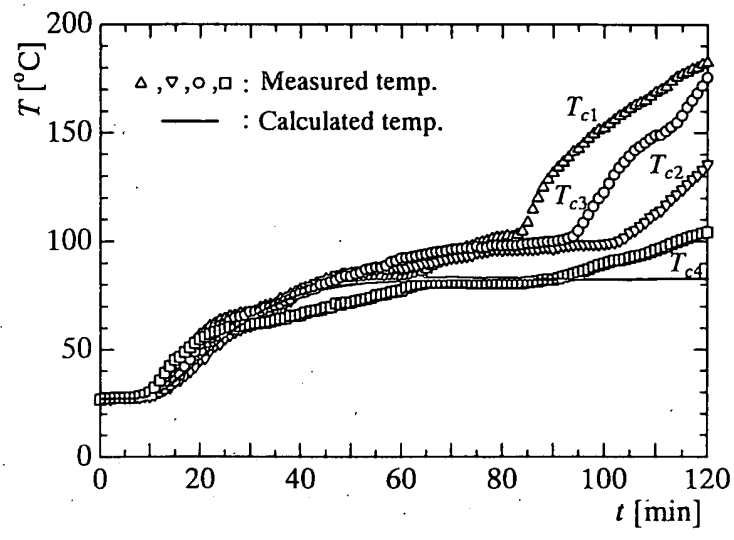

Fig. 5 Comparison between measured and calculated results

行った。対象は厚さ $100 \mathrm{~mm}$ のロックウール単一層であ り、熱伝導率を $\lambda=0.08 \mathrm{~W} / \mathrm{mK}$ 、嵩密度を $\rho=80 \mathrm{~kg} / \mathrm{m}^{3}$ 、比熱 を $c=810 \mathrm{~J} / \mathrm{kgK}$ 、初期および周囲空気温度を $T_{a}=20^{\circ} \mathrm{C}$ 、加 熱面側熱伝達係数を $\alpha_{g}=50 \mathrm{~W} / \mathrm{m}^{2} \mathrm{~K}$ 、裹面側熱伝達係数を $\alpha_{a}=3 \mathrm{~W} / \mathrm{m}^{2} \mathrm{~K}$ とした。図 3 に結果を示す。両者は非常に 良く一致しており、本プログラムコードにより良好な結 果が得られていることがわかる。

図 4 に、図 2 の積層型耐火壁を対象として行った数值 解析結果を示す。(a)〜 (f)の各曲線の壁内位置は図中に 示す通りである。ここで、ケイ酸カルシュウム(ケイカル) 板に関しては $\lambda=0.145 \mathrm{~W} / \mathrm{mK} 、 \rho=800 \mathrm{~kg} / \mathrm{m}^{3} 、 c=1000 \mathrm{~J} / \mathrm{kgK}$ とし、ロックウールに関しては $\lambda=0.08 \mathrm{~W} / \mathrm{mK} 、 \rho=80 \mathrm{~kg} / \mathrm{m}^{3}$ 、 $c=800 \mathrm{~J} / \mathrm{kgK}$ 、また $T_{\mathrm{a}}=27^{\circ} \mathrm{C} 、 \alpha_{g}=10 \mathrm{~W} / \mathrm{m}^{2} \mathrm{~K} 、 \alpha_{a}=3 \mathrm{~W} / \mathrm{m}^{2} \mathrm{~K}$ とし、ケイカル板内の含水量は $3.0 \mathrm{wt} \%$ とた。加熱開始 後約 40〜100min におけるロックウールとその近傍の温

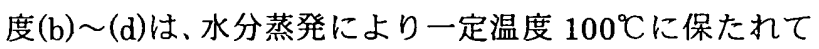
いる。また、これに呼応して裏面側ケイカル板温度 (e)、 (f)も約 $80^{\circ} \mathrm{C}$ に保持されている。燃焼ガス側のケイカル 板内温度 (a) は約 $40 \mathrm{~min}$ 後から階段状に上昇しているが、 これはそのすぐ近傍のケイカル板内における水分蒸発の 影響を受けたためと考えられる。㜣焼ガス側のケイカル 板内の水分が全て蒸発する約 $100 \mathrm{mim}$ 以後には、(a)〜 (d) に示されているように急速な温度上昇が見られる。

図 5 に、耐火試験による測定結果と数值解析結果の比 較を示す。温度測定位置は、図 1 に示したように裹面側 ケイカル板の継ぎ目 $\left(T_{c 1}, T_{c 2}\right)$ 、ケイカル板表面 $\left(T_{c 3}\right)$ 、金 属スタッド(間柱, $T_{c 4}$ ) 部分にあたる計 4 点である。両者は 加熱開始後約 $60 \mathrm{~min}$ まではほほ一致した。しかし、測定 結果の方は所々で階段状の変化が見られ、80min を越え たあたりからは急速に温度上昇している。これらの原因 については、燃焼ガス側ケイカル板の亀裂や破壊、数值 シミュレーションにおいて省略した継ぎ目や金属スタッ ドなどの影響が考えられ、現在検討中である。

\section{4. 結言}

空気層や水分を含む建築用耐火壁を片面側から非定常 加熱し、その裹面側を自然放冷させた場合(建築用耐火試 験)の 1 次元数值シミュレーションを行い、裏面温度に関 する耐火試験結果と数值解析結果を比較・検討した。

\section{参 考文 献}

(1) 吉岡 - 小池 - 茶谷、建築一構成と材料、丸善 (1982) pp.68-70. 